\title{
Work Domain Analysis and Intelligent Transport Systems: Implications for Vehicle Design
}

\author{
Paul M. Salmon ${ }^{1 *}$, Michael Regan², Michael \\ G. Lenné2, Neville A. Stanton ${ }^{1}$, and Kristie \\ Young $^{2}$
}

${ }^{1}$ Human Factors Integration Defence Technology Centre (DTC-HFI), Brunel University, BIT Lab, School of Engineering and Design, Uxbridge, Middlesex, UK, UB8 3PH

2 Monash University Accident Research Centre (MUARC), Building 70, Monash University, Victoria, 3800, Australia

*Corresponding author, email: paul.salmon@brunel.ac.uk

\begin{abstract}
Work domain analysis (WDA) allows designers to model systems based on their purposive, functional and physical constraints, and has previously been used to inform system design and analysis in complex sociotechnical systems. This article presents a WDA of the road transport system in Victoria, Australia. The findings are discussed with regard to their implications for the use of intelligent transport systems (ITS) in future vehicles. Specifically, a series of driver information requirements and driving tasks that could potentially be supported through vehicle design were extracted from the WDA. The potential use of ITS technologies to support these requirements and tasks is discussed. In summary, the WDA indicates that driver information requirements are not entirely satisfied by contemporary vehicle design, and additionally that there are a number of driving tasks that could be further supported through the provision of supplementary systems within the vehicle. It is concluded that there is potential for using various ITS technologies to circumvent these information gaps and provide this additional support to drivers.
\end{abstract}

Keywords: Cognitive Work Analysis, Work Domain Analysis, Road Transport, Vehicle Design, Intelligent Transport Systems.

Reference to this paper should be made as follows: Salmon, P. M., Regan, M., Lenné, Stanton, N. A., \& Young, K. L. (2006). Work domain analysis and intelligent transport systems: Implications for vehicle design, Vol. X, No. Y,pp.000-000.

Biographical Notes: Paul Salmon is a Human Factors Research Fellow within the Human Factors Group at Brunel University and holds a BSc in Sports Science and an MSc in Applied Ergonomics, (both from the University of Sunderland). Paul has over five years of experience in applied human factors research in a number of domains, including the military, civil and general aviation, rail and road transport. Paul has expertise in a broad range of areas, including human error, situation awareness, and the application of human factors methods, including human error identification, situation awareness measurement, teamwork assessment, task analysis and cognitive task analysis methods. 


\section{Introduction}

The principles of Ecological Interface Design (EID) are used to aid the design of human-centred interfaces and systems that support problem solving, decision-making and knowledge-based behaviour in complex sociotechnical systems. An ecologically designed interface is one that has been designed to reflect the constraints of the system in a way that is perceptually available to the people performing activity within it, and one that supports users in taking effective action and understanding how these actions will move them towards the achievement of their goals (Burns \& Hajdukiewicz, 2004). One EID-based approach that is currently receiving increasing attention from the human factors community is the Cognitive Work Analysis framework (CWA; Vicente, 1999). CWA uses a range of methods to analyse the various constraints that are imposed on activity within a particular system. The CWA framework comprises five phases: Work Domain Analysis (WDA), control task analysis, strategies analysis, social organisation and co-operation analysis, and worker competencies analysis. A brief description of each phase is provided below.

1. Work Domain Analysis. The first phase involves modelling the functional structure of the system in which the activity takes place. A WDA is used to identify the functional purposes and structure of the system in terms of the overall system purposes, the processes adopted, and the artefacts used within the system. In modelling a system in this way, the systemic constraints that shape activity are specified. WDA involves developing an Abstraction Decomposition Space (ADS) for the system in question.

2. Control Task Analysis. The second phase is used to determine the tasks that are undertaken within the system under analysis. According to Naikar, Moylan and Pearce (In Press), control task analysis complements WDA by identifying the activity that is necessary to achieve the purposes, priorities and values, and functions of a work domain with a set of physical resources. Activities are identified irrespective of how they are performed or who performs them. Typically, the decision ladder approach (Rasmussen, 1976) is used for the control task analysis component of the CWA framework.

3. Strategies Analysis. The third stage is used to identify how the different tasks could potentially be conducted, and involves the identification of strategies that agents might employ when performing control tasks. The strategies analysis component uses information flow maps to identify different cognitive procedures that might be employed during the conduct of control tasks.

4. Social Organisation and Co-operation Analysis. The fourth phase is used to identify how the activity and the associated strategies required are distributed amongst agents and artefacts within the system. Social organisation and co-operation analysis uses a combination of the ADS, decision ladder, and information flow maps.

5. Worker Competencies Analysis. The fifth and final stage involves identifying the cognitive skills that agents employ during control task performance. Worker competencies analysis uses Rasmussen's Skill, Rule, and Knowledge (SRK) framework in order to classify the cognitive activities employed by agents during control task performance.

The different CWA phases allow practitioners to specify the constraints related to where, why and with what the activity under analysis is conducted (work domain 
analysis), what activity is conducted (control task analysis), how the activity is conducted (strategies analysis and worker competencies analysis), and also who the activity is conducted by (social organization and co-operation analysis). The flexibility of the CWA framework is such that it has been used in a number of domains for a range of purposes. A literature review identified CWA applications in the following domains: aviation (e.g., Naikar \& Sanderson, 2001); process control (e.g., Vicente, 1999); nuclear power (e.g., Olsson and Lee, 1994); Naval (e.g., Bisantz, Roth, Brickman, Gosbee, Hettinger \& McKinney, 2003); military command and control (e.g., Salmon, Stanton, Walker \& Green, 2004); road transport (e.g., Stoner, Wiese and Lee, 2003); health care (e.g., Miller, 2004); air traffic control (e.g., Ahlstrom, 2005); and manufacturing (e.g., Higgins, 1998). These CWA applications can be broadly categorised as follows: system modelling (e.g. Hajdukiewicz, 1998); system design (e.g. Bisantz et al, 2003); training needs analysis (e.g. Naikar and Sanderson, 1999), training program evaluation and design (e.g. Naikar and Sanderson, 1999); interface design and evaluation (Vicente, 1999); information requirements specification (e.g. Ahlstrom, 2005); tender evaluation (Naikar and Sanderson, 2001); team design (Naikar, Pearce, Drum \& Sanderson, 2003); and error management strategy design (Naikar and Saunders, 2003).

Despite its extensive use across many domains, evidence of road transport-related CWA applications is sparse. It is apparent, however, that there is great potential for applying the framework within road transport. For example, in conclusion to a study investigating the potential application of CWA-related methods within the road transport domain, Salmon, Stephan, Lenné and Regan (2005) identified a range of potential applications, including vehicle interface design and driver information requirements analysis.

The aim of this research was to investigate the application of CWA-related methods in the road transport domain, in particular the use of WDA for conducting information requirements analysis during the design process. A WDA of the road transport system in Victoria, a jurisdiction located in Australia, was conducted. The output of the WDA was then used to conduct an information requirements analysis for drivers. This allowed us to identify the different types of information that vehicle drivers require for safe, compliant and efficient driving. Further, the WDA was used to identify a range of driving tasks that, in the author's opinion, could potentially be supported more efficiently through vehicle design. Finally, the suitability of using a range of different ITS technologies identified in the literature to satisfy the informational and task support requirements identified by the WDA was explored.

\section{STUDY}

\subsection{Work Domain Analysis of the Victorian Road Transport System}

WDA involves the construction of an Abstraction Decomposition Space (ADS), which provides a two-dimensional representation of the system under analysis (Vicente, 1999). Each of the cells within the ADS presents a different representation of, or 'way of thinking about', the same system. For example, the top left cell in an ADS describes the functional purposes of the entire system (e.g., why the system exists and what its primary purposes are), whilst the bottom right cell describes the physical components that comprise the system (e.g. the people, objects, tools and technological artefacts used 
within the system). The ADS comprises a combination of an abstraction hierarchy and a decomposition hierarchy. The abstraction hierarchy consists of five levels of abstraction, ranging from the most abstract level of purposes to the most concrete level of form (Vicente, 1999). A description of each of the five abstraction hierarchy levels is given below (Source: Naikar, Hopcroft and Moylan, 2005).

- Functional purpose - The overall purposes of the system and the external constraints on its operation;

- Abstract function - The criteria that the system uses for measuring progress towards the functional purposes;

- Generalised function - The general functions of the work system that are necessary for achieving the functional purposes;

- Physical function - The functional capabilities and limitations of the physical objects within the system that enable the purpose-related functions; and

- Physical form - the physical objects within the work system that affords the physical functions.

The decomposition hierarchy uses five levels of resolution, ranging from the broadest level of total system to the finest level of component, comprising total system, subsystem, function unit, sub-assembly and component (Vicente, 1999). WDA is flexible in that all of the cells within the ADS do not need to be populated during the course of an analysis. The ADS also employs structural means-ends relationships in order to link the different representations of the system. This means that every node in the ADS should be the end that is achieved by all of the linked nodes below it, and also the means that (either on its own or in combination with other nodes) can be used to achieve all of the linked nodes above it. To put the example into a road transport context, this would mean that the functional purpose-total system node 'Safe, efficient, comfortable and enjoyable road transport' could be linked below to the abstract function-total system nodes 'Traffic laws, rules and regulations' and 'law enforcement'. That is, one of the ways in which to ensure safe, efficient, comfortable and enjoyable road transport is through the use of appropriate road traffic laws and legislation and the enforcement of these laws. Alternatively, the physical function-component node 'vehicle capability' (acceleration, power, fuel economy etc) could be linked above to the generalised function-component node 'vehicle dynamics' (movement, direction, speed etc). That is, the various features of vehicle capability afford the vehicle dynamics. A high level example of the some of the meansends relationships within a typical road transport system is presented in Figure 1. 


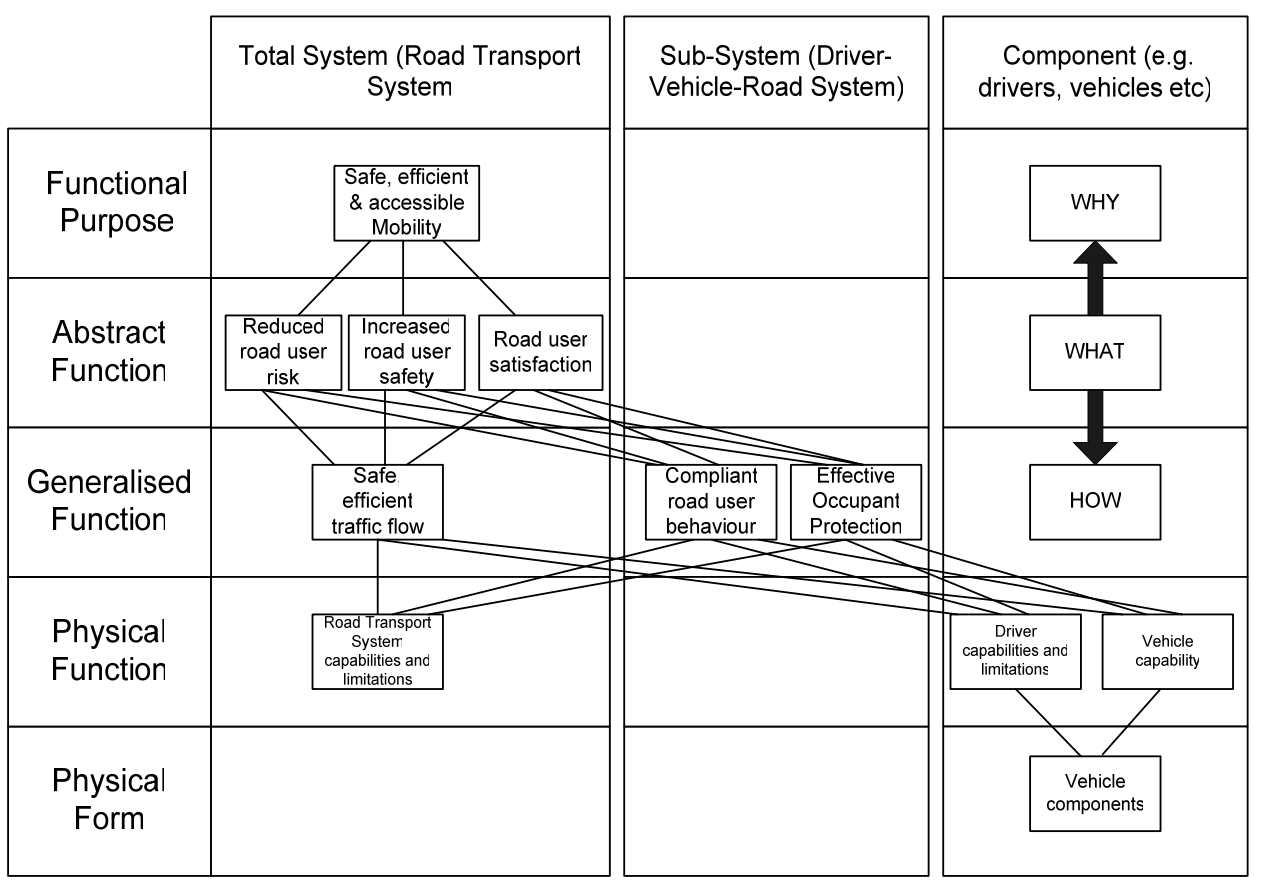

Figure 1. Example of the means-ends relationships within a typical road transport system.

\subsection{Methodology}

The links presented in Figure 1 represent the means-ends relationships between the purposes and functions specified. Within Figure 1, the functions and purposes presented are the end that is achieved by those linked below them, and also the means that can be used to achieve those linked above them (this is represented by the why, what, how arrow diagram located in the top right hand side of Figure 1). For example, within a road transport system, the functional purpose of safe, efficient and accessible mobility can be achieved through abstract functions such as reducing road user risk levels, and increasing road user safety and satisfaction. These abstract functions can be achieved through generalised functions such as safe and efficient traffic flow, compliant road user behaviour and effective occupant protection. Safe and efficient traffic flow is a function of the capabilities and limitations of the road transport system, the drivers and their vehicles. Finally, vehicle capability is a function of the different vehicle components.

A WDA of the Victorian road transport system was conducted. This involved developing an ADS for the road transport system in Victoria using a step-by-step WDA methodology described by Naikar et al (2005). In summary, this involved the following steps:

Step 1: Establish purpose of the WDA

The first step involved clearly defining the purpose of the WDA. According to Naikar et al. (2005), this involves two parts: defining the problem that is to be addressed or resolved; and defining how the WDA will be used to address the problem. For this research, the purpose of the WDA is related to the information requirements of drivers whilst driving and the use of supplementary in-vehicle systems to support these 
information requirements and other driving tasks. The WDA was used to develop a functional model of the Victorian road transport system from the point of view of a driver that could then be used to identify the different categories of information that a driver requires while driving and the different driving tasks that drivers might require additional support on.

Step 2: Identify Project Constraints

It is important to identify any constraints associated with the project that may impact the conduct of the WDA. In this case, a number of project constraints were identified including: the financial and time constraints associated with the project, the geographical region on which the project was focussed (i.e. Victoria), and personnel and expertiserelated constraints. These constraints impacted the WDA in that the scope had to be reduced (due to time and financial constraints) from focussing on the complete road transport system and all of its stakeholders to focussing primarily on the driver and the Victorian road transport system.

Step 3: Determine Boundaries of the WDA

WDA analyses can become large, complex and unwieldy. Clearly stating the boundaries of the WDA is useful in order to maintain its focus and scope. This involves defining specifically the component of the system that will be the focus of the study. This might involve identifying a smaller part of an overall system that is to be the focus of the analysis. The boundaries identified in this case were that the WDA should focus only on the road transport system from the point of view of the driver and not other road transport stakeholders (such as police, government bodies, pedestrians, vehicle manufacturers, etc), and that only the Victorian (as opposed to the entire Australian) road transport system should be considered.

Step 4: Identify Nature of Constraints

According to Naikar et al. (2005), the next step in the conduct of a WDA involves identifying the point on the causal-intentional continuum the focus system falls. The purpose of this is to gain an insight into the nature of the constraints that should be modelled in the WDA (Hajdukiewicz et al., 1999; cited in Naikar et al., 2005). Naikar et al. (2005) describe five categories of work systems that can be used to identify where a particular system lies on the causal-intentional continuum. It was concluded that the Victorian road transport system falls somewhere between the third and fourth categories specified. That is, the Victorian road transport system can be classified both as a 'system governed by actors intentions' and a 'system governed by actors personal objectives'. It was therefore concluded that the nature of the constraints that should be modelled by the WDA are intentional constraints based on organisational policies, plans, legislation and other forms of regulation, social laws and conventions, actors intentions or motives, highlevel institutional objectives and actors goals and personal objectives.

Step 5: Identify Potential Sources of Information

There were many sources of information that could potentially inform the Victorian road transport system WDA. These include documents relating to road traffic rules, regulation, legislation and policy, driver training, road infrastructure design, traffic engineering, accident and incident reports, road maps, driver education programs, road transport engineering and so on. Further, interviews and brainstorming sessions with appropriate 
road transport subject matter experts (SMEs) were also identified as potential sources of information. Due to the financial and time constraints imposed on the project, the following sources of information were used to inform the WDA:

- Brainstorming sessions with SMEs (experienced drivers, road transport and road safety researchers, experimental psychologists);

- Road traffic rules, regulations, legislation and policy documentation;

- Governing body websites (e.g., VicRoads, Transport Accident Commission);

- Existing driver training manuals;

- Personal experience of the road transport system; and

- Road transport-related engineering documents.

Step 6: Construct initial ADS

The next step involved constructing an initial ADS for the Victorian road transport system, using only analyst judgement and the most readily available sources of information. This involved the following steps, based on Naikar et al.'s (2005) WDA methodology:

- Identification of the work domain properties;

- Definition of appropriate levels of abstraction and decomposition;

- Development of an initial 'sketch' of the ADS;

- Identification of the ADS cells that should be populated; and

- Population of the selected ADS cells.

Step 7: ADS - Second Iteration

A second iteration of the ADS was then conducted using additional sources of information to those used during the first iteration. This involved the conduct of a brainstorming session and interviews with road safety researchers, human factors specialists, and experimental psychologists. The brainstorming and interview sessions involved walking through a series of WDA prompt questions presented by Naikar et al (2005).

It is beyond the scope of this article to present the complete ADS for the Victorian road transport system. Rather, a summary of the ADS is presented in Table 1. Within the ADS, each cell contains summary headings for the different categories of functions and purposes identified. For example, the external constraint road traffic rules and regulations is a summary heading for all of the different rules and regulations that are applicable within the Victorian road transport system, including the Australian Road Rules 1999, Road Safety Regulations 1999, Road Vehicle Regulations 1999, Road Driver Regulations 1999, Transport Regulations 1993, Road Management Regulations 2004, and the Road Management Act 2004. Likewise, the heading road infrastructure refers to everything within the road transport system that can be classed as road infrastructure, including traffic control devices (traffic lights, speed cameras), road signage, infrastructure such as bridges, pedestrian crossings, pavements and so on. 
Table 1. Road Transport ADS Summary Table

\begin{tabular}{|c|c|c|c|}
\hline & $\begin{array}{c}\text { Total System (Victorian Road } \\
\text { Transport System) }\end{array}$ & Sub-System (Driving System) & Component (Road users, vehicles etc) \\
\hline $\begin{array}{l}\text { Functional } \\
\text { Purpose }\end{array}$ & $\begin{array}{l}\text { Primary Objectives: Safe, efficient, accessible } \\
\text { \& comfortable Mobility } \\
\text { Safe, efficient transportation of people and } \\
\text { goods } \\
\text { External Constraints: Road rules and } \\
\text { regulations }\end{array}$ & & $\begin{array}{l}\text { Road users: Fulfillment of personal and social } \\
\text { goals } \\
\text { Vehicles: To provide the means for safe, efficient } \\
\text { and comfortable mobility/transportation }\end{array}$ \\
\hline Abstract Function & $\begin{array}{ll}: & \text { Road user risk Level } \\
\text { Crash, injury, fatality incidence \& } \\
\text { probability e.g road toll, crash databases } \\
\text { : Road user satisfaction } \\
\text { Road user compliance } \\
\text { : } & \text { Covel times } \\
& \text { Congestion levels } \\
\end{array}$ & & 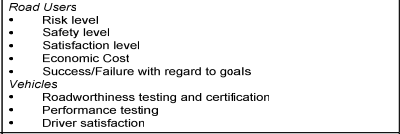 \\
\hline $\begin{array}{l}\text { Generalised } \\
\text { Function }\end{array}$ & $\begin{array}{ll}\text { : } & \text { Safe \& efficient traffic flow } \\
: & \text { Law enforcement } \\
\text { Safe \& compliant road user behaviour } \\
\text { System inspection, maintenance anc } \\
\text { upgrade }\end{array}$ & - Safe, efficient \& compliant driving & $\begin{array}{l}\text { Drivers } \\
\text { Physical vehicle control } \\
\text { Cognitive Processes e.g hazard perception, } \\
\text { situation awareness, information processing } \\
\text { attentional control etc } \\
\text { Vehiclest } \\
\begin{array}{l}\text { Physical dymanics } \\
\text { Occupant protection }\end{array} \\
\end{array}$ \\
\hline Physical Function & $\begin{array}{l}\text { - Road transport system functiona } \\
\text { - capability and limitations } \\
\text { Traffic dynamics }\end{array}$ & $\begin{array}{ll}\text { : } & \text { Direct road users } \\
: & \text { Inform road users } \\
: & \text { Afford road user movement } \\
: & \text { Restrict/Control road users } \\
: & \text { Occupant protection } \\
\text { Lower and higher order cognitive } \\
\text { processes } \\
\text { physical dynamics e.g. movement }\end{array}$ & 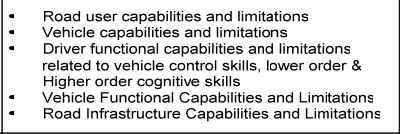 \\
\hline Physical Form & 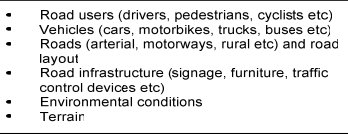 & & \begin{tabular}{|l|} 
- Vehicle type, manufacturer, model, colour, \\
- external form etc \\
Vehicle components e.g. Engine chassis and \\
body components, Cockpit components, Interior \\
components etc \\
Road infrastructure components e.g. traffic \\
control device components, road signage \\
components, roadway components etc
\end{tabular} \\
\hline
\end{tabular}

\section{Implications for Vehicle Design}

Whilst a number of general conclusions regarding the road transport system can be taken from the ADS (see Salmon et al, 2005), it is the implications for vehicle design that are the primary focus of this article. This article focuses on these implications in two areas: firstly, the different types of information that should be presented to drivers (i.e. information requirements), in particular the information that is presented to the drivers by systems within the vehicle; and secondly on the support that in-vehicle systems could potentially provide to drivers during certain elements of the driving task.

\subsection{Information Requirements}

The information that is presented by an interface to its end-users, and the form in which the information is presented are critical features to consider during the design process. Failing to present required information or presenting information that is not required, presenting information in an inappropriate manner, or presenting too much information can potentially have a detrimental effect upon task performance. ADS outputs have previously been used to identify the different types of information that users require when using a device or system. These so called 'information requirements' can then be used to inform design by specifying what information a particular device or system should present to its users. According to Ormerod \& Shepherd (2005) information requirements comprise the data that an agent needs in order to accomplish a task safely and efficiently.

ADS outputs can be used to identify the information requirements for a particular system. Potentially, each of the cells within an ADS can be used to define a set of 
information requirements for a particular device or interface that will support the user whichever way they are using, or thinking about, the system in question. For example, Salmon et al. (2004) used the ADS in this way to specify the information requirements for a command and control knowledge wall display and for unmanned aerial and ground vehicle controller interfaces. Stoner et al. (2003) used an ADS to identify the different types of information that driver support systems should be presenting to drivers. Ahlstrom (2005) also describes the use of an ADS for determining the types of information that air traffic controllers require for effective performance during adverse weather conditions. We therefore argue that the ADS of the Victorian road transport system can be used to identify different categories of information that drivers require to support safe, compliant and efficient driving. A series of information requirements for drivers were extracted from the ADS presented in Table 1. These driver information requirements are presented in Table 2. Within Table 2, information requirements related to each cell within the ADS presented in Table 1 are specified. For example, the functional purpose of 'safe, efficient, accessible and comfortable mobility' (from Table 1) can be translated into the information requirement of 'rules and regulations' (presented in Table 2). That is, for drivers to drive safely they require information related to the rules and regulations of the road transport system (e.g. speed limits, right of way, vehicle roadworthiness regulations etc).

Table 2. Driver information requirements based on ADS of Victorian road transport system

\begin{tabular}{|c|c|c|c|}
\hline & $\begin{array}{c}\text { Total System (Victorian Road } \\
\text { Transport System) }\end{array}$ & Sub-System (Driving System) & Component (Road users, vehicles etc) \\
\hline $\begin{array}{l}\text { Functional } \\
\text { Purpose }\end{array}$ & Road Rules and Regulations e.g. Speed Limits & & $\begin{array}{c}\text { Driver Goals } \\
\text { Safety Level } \\
\text { Vehicle Performance e.g. MPG } \\
\text { Vehicle Condition e.g. Date next service due }\end{array}$ \\
\hline Abstract Function & $\begin{array}{l}\text { Road Rules and Regulations e.g. Speed Limits } \\
\text { Crash, injury, fatality incidence \& probability } \\
\text { Safety/Risk level } \\
\text { Travel times } \\
\text { Congestion levels }\end{array}$ & & $\begin{array}{l}\text { Economic cost of planned/alternative journeys } \\
\text { Risk/Safety leve } \\
\text { Progress towards goal(s) } \\
\text { Vehicle performance and status } \\
\text { Vehicle Roadworthiness e.g. MOT expiration warning }\end{array}$ \\
\hline $\begin{array}{l}\text { Generalised } \\
\text { Function }\end{array}$ & $\begin{array}{l}\text { Road Rules and Regulations e.g. Speed Limits } \\
\text { Warnings e.g. sharp bend, slippery surface } \\
\text { Behavioural Recommendations e.g. Slow } \\
\text { down, watch for school children etc }\end{array}$ & \begin{tabular}{|l|} 
Road Rules and Regulations e.g. Speed \\
Limits \\
Warnings e.g. sharp bend, slippery surface \\
Behavioural Recommendations e.g. Slow \\
down, watch for school children etc
\end{tabular} & $\begin{array}{l}\text { Physical vehicle control task support } \\
\text { Cognitive vehicle control task support } \\
\text { Speec }\end{array}$ \\
\hline Physical Function & Road Transport System Limitation Warnings & \begin{tabular}{|c|} 
Route directions \\
Road Signage Information \\
Current location and desired end point \\
Congestion information \\
Occupant protection enforcement \\
Physical dynamics (own and other vehicles;
\end{tabular} & $\begin{array}{l}\text { Driver condition/fitness to drive } \\
\text { Vehicle condition } \\
\text { vehicle Capability } \\
\text { Current task status in relation to goals }\end{array}$ \\
\hline Physical Form & $\begin{array}{l}\text { Road type (arterial, motorways, rural etc'; } \\
\text { Road name (e.g. M1, M25) } \\
\text { Road Signage Information } \\
\text { Traffic Control Device Information } \\
\text { Environmental conditions (current and } \\
\text { projected) }\end{array}$ & & $\begin{array}{l}\text { Current component performance and status } \\
\text { Vehicle component condition e.g. tyres } \\
\text { Other road users/vehicles (location, proximity, speed } \\
\text { future movements etc) }\end{array}$ \\
\hline
\end{tabular}

The information requirements presented in Table 2 represent the different categories of information that a driver requires for safe, compliant and efficient driving, based on the WDA presented in Table 1 . The next step of this research involved determining whether the information requirements presented in Table 2 are currently adequately presented to drivers by contemporary production vehicles. The extent to which this information is already presented to drivers within contemporary production vehicles is represented in Table 3. Within Table 3, a judgement as to whether each information 
requirement (as specified in Table 2) is currently supported in contemporary production vehicles. For example, the information requirement 'travel times' is currently presented by route navigation systems, whereas the information requirement 'road rules and regulations' is not currently presented to drivers within contemporary production vehicles (i.e. this is information is currently presented to drivers via road signage).

Table 3. Information requirement presentation in contemporary production vehicles

\begin{tabular}{|c|c|c|}
\hline \multirow[t]{2}{*}{ Information Requirement } & $\begin{array}{l}\text { Presented Within } \\
\text { Contemporary } \\
\text { Vehicles? }\end{array}$ & \multirow{2}{*}{$\begin{array}{l}\text { System } \\
\text { *Denotes systems that are fitted as } \\
\text { standard to several (but not all) } \\
\text { production vehicles }\end{array}$} \\
\hline & Yes & \\
\hline \multicolumn{3}{|l|}{ Road Rules and Regulations } \\
\hline \multicolumn{3}{|l|}{ Crash, injury, fatality probability } \\
\hline \multicolumn{3}{|l|}{ Risk level } \\
\hline Travel Times & & *Route navigation systems \\
\hline Congestion levels & & Radio systems \\
\hline Economic cost of trip & & $\begin{array}{l}\text { *Trip computer display, *Economy } \\
\text { dials }\end{array}$ \\
\hline Progress towards goal & & *Route navigation systems \\
\hline Driver goals & & *Route navigation systems \\
\hline \multicolumn{3}{|l|}{ Driver condition/fitness to drive } \\
\hline \multicolumn{3}{|l|}{ Vehicle condition } \\
\hline Vehicle performance & & Vehicle diagnostics display \\
\hline Route directions & & *Route navigation systems \\
\hline Current location and desired end point & & *Route navigation systems \\
\hline \multicolumn{3}{|l|}{ Location of other road users } \\
\hline \multicolumn{3}{|l|}{ Proximity of other road users/objects } \\
\hline Physical dynamics of own vehicle & & In-vehicle displays e.g. Speedometer \\
\hline \multicolumn{3}{|l|}{ Physical dynamics of other vehicles } \\
\hline Occupant protection information & & Seat-belt reminder systems \\
\hline Road type & & *Route navigation systems \\
\hline Environmental/Road conditions & & Radio/*route navigation systems \\
\hline \multicolumn{3}{|l|}{ Road signage } \\
\hline \multicolumn{3}{|l|}{ Behavioural Recommendations } \\
\hline \multicolumn{3}{|l|}{ Infrastructure Related Warnings } \\
\hline \multicolumn{3}{|l|}{ Traffic Control Device information } \\
\hline Vehicle Roadworthiness & & *Service warnings, Fault diagnostics \\
\hline Vehicle Component Condition & & Engine/Oil/Break warning light \\
\hline
\end{tabular}

In summary, of the information requirements specified in Table 2, it is concluded that within contemporary production vehicles, the following categories of information are not currently presented in their entirety:

- $\quad$ Road rules and regulations e.g. speed limits, right of way etc;

- $\quad$ Road signage;

- Behavioural recommendations e.g. 'slow down';

- Infrastructure related warnings e.g. 'sharp bend ahead', 'slippery surface ahead';

- Crash, injury, fatality probability;

- Traffic control device information;

- $\quad$ Risk level; 
- Driver fitness to drive;

- Vehicle condition and roadworthiness;

- Location of other road users (including vehicles, bicyclists and pedestrians etc);

- Proximity of other road users/objects; and

- Physical dynamics of other vehicles.

Interestingly, of the information requirements that are currently satisfied within contemporary production vehicles, it is apparent that the majority of this information is presented via route navigation systems. It is notable that such systems are not yet a standard feature throughout the full range of production vehicles, particularly at the lower end of the market, and also that route navigation systems are typically purchased off the shelf and integrated into existing vehicle cockpits.

\subsection{Driver Support}

The ADS presented in Table 1 was also used to identify different elements of the driving task for which drivers might require additional support from the vehicle during driving. Features of the driving task that could potentially be supported, and which, in the author's opinion at least, are not in contemporary production vehicles, were extracted from the ADS. The aspects of the driving task that could potentially be supported through supplementary systems within the vehicle:

- Road sign presentation and delineation;

- Understanding/comprehension of road rules (e.g., speed limit);

- Understanding and comprehension of the location/future actions of other road users;

- Physical vehicle control tasks;

- Cognitive vehicle control tasks;

- Compliant driving; and

- Ensuring the driver is fit to drive.

It is the opinion of the authors that the unsupported information requirements and tasks identified above could be supported effectively through the provision of a range of ITS technologies, either currently available or in prototype form. In the following section we propose ITS-based solutions (taken from the literature on ITS technologies) for the information gaps and driver support requirements described above.

\subsection{Intelligent Transport Systems}

ITS technologies are increasingly being used in a number of ways within modern vehicles to enhance driver performance and safety. ITS refers to the application of electronic, computer and information and communication technologies to vehicles and roadways to enhance safety, reduce congestion, enhance mobility, minimise environmental impact, increase energy efficiency and promote productivity (Regan, 
2004a). According to Regan (2005), ITS technologies are at various stages of development: some already exist in production vehicles, some exist only as prototypes and some are at the developmental stage. Examples of ITS technologies include route navigation systems, adaptive cruise control systems, and intelligent speed adaptation systems. Regan (2005) broadly classifies ITS technologies into the following three categories: 1 . Vehicle-based ITS. These comprise on-board sensors that collect data, onboard units that receive and process the data, and on-board displays that present the data via messages and warnings to the driver; 2. Infrastructure-based ITS. Comprise roadside sensors that collect data that is transmitted to drivers via roadside equipment such as variable message signs (VMS); and 3. Cooperative ITS. Collect data from the road infrastructure, remote sensors and other vehicles and transmit these data to the driver through VMS or in-vehicle displays.

Despite the projected safety benefits associated with ITS, consumer demand is currently minimal and the actual safety benefits associated with most ITS technologies remain largely unknown (Regan, Young, Triggs, Tomasevic, and Mitsopoulos, Tierney, Healy, Connelly, \& Tingvall, 2005). Consequently, typically only luxury or top-end production vehicles possess such systems. However, it is clear that the integration of ITS technologies within the vehicle cockpit, if done correctly, could potentially have a range of safety and performance benefits, and a number of empirical research studies have demonstrated this (e.g. Regan et al, 2005). The potential use of ITS technology to compensate for the current information gaps identified above and to support the driver in a range of tasks is evident. To demonstrate this, each of the cells within the ADS presented in Table 1 was populated with ITS technologies (taken from the literature on ITS technologies) that could potentially be used to present the information requirement for that particular cell (from Table 2). Further, ITS devices that could potentially support the driver, or enhance driver performance on the tasks identified above, were also added. A summary of the ITS technologies considered, either currently available or in prototype form, is presented in Table 4 (adapted from Regan et al, 2005). 
Table 4. Summary of contemporary ITS technologies

\begin{tabular}{|c|c|}
\hline ITS Technology & Function \\
\hline $\begin{array}{l}\text { Intelligent Speed } \\
\text { Adaptation Systems }\end{array}$ & $\begin{array}{l}\text { Warns the driver when driving in excess of the current speed limit. Also informs } \\
\text { the driver of current speed limit. Limiting systems are also available which } \\
\text { prevent the speed limit from being exceeded }\end{array}$ \\
\hline Adaptive Cruise Control & Maintains selected cruise speed and following distances. \\
\hline $\begin{array}{l}\text { Forward Collision } \\
\text { Warning Systems }\end{array}$ & Warns driver in event of likely collision with objects in front of vehicle \\
\hline $\begin{array}{l}\text { Rear Collision Warning } \\
\text { Systems }\end{array}$ & Warns driver in event of likely rear impact \\
\hline Seat Belt Reminder & Warns driver if any vehicle occupants have not put their seatbelt on \\
\hline Seat Belt Interlock & $\begin{array}{l}\text { Prevents the vehicle from being driven if a vehicle occupant fail to put their } \\
\text { seatbelt on }\end{array}$ \\
\hline Alcohol Interlock & $\begin{array}{l}\text { Prevents the vehicle from being started if the driver is inebriated or above a } \\
\text { particular alcohol threshold }\end{array}$ \\
\hline $\begin{array}{l}\text { Lane Departure Warning } \\
\text { Systems }\end{array}$ & $\begin{array}{l}\text { Warns driver in advance of the vehicle is about to move from lane or drive off } \\
\text { the road }\end{array}$ \\
\hline $\begin{array}{l}\text { Lane Keeping } \\
\text { Assistance Systems }\end{array}$ & Uses vision technology and steering actuation to keep vehicle in lane \\
\hline $\begin{array}{l}\text { Brake Assist/Forward } \\
\text { Collision Mitigation }\end{array}$ & Optimises braking performance in the event of impending collision \\
\hline $\begin{array}{l}\text { Following Distance } \\
\text { Warning System }\end{array}$ & $\begin{array}{l}\text { Warns the driver when distance between own vehicle and vehicle in front } \\
\text { (following distance) is too short }\end{array}$ \\
\hline $\begin{array}{l}\text { Pedestrian Detection and } \\
\text { Warning Systems }\end{array}$ & Detects pedestrians in close proximity to the vehicle and warns driver \\
\hline $\begin{array}{l}\text { Intersection Collision } \\
\text { Warning Systems }\end{array}$ & $\begin{array}{l}\text { Warns the driver when on imminent collision course with another vehicle where } \\
\text { external vision is limited or there are blind spots }\end{array}$ \\
\hline $\begin{array}{l}\text { Side Object Warning } \\
\text { Systems }\end{array}$ & $\begin{array}{l}\text { Assists driver in changing lanes by detecting vehicles behind and located within } \\
\text { the blind spot }\end{array}$ \\
\hline $\begin{array}{l}\text { Electronic Driver } \\
\text { Licence systems }\end{array}$ & Prevents unlicensed drivers from starting the vehicle. \\
\hline $\begin{array}{l}\text { Vigilance Monitoring } \\
\text { Systems }\end{array}$ & $\begin{array}{l}\text { Monitor drivers eyes off road time and warns the driver if the drivers eyes are } \\
\text { off the road for too long a duration }\end{array}$ \\
\hline $\begin{array}{l}\text { Fatigue } \\
\text { Detection/Warning } \\
\text { Systems }\end{array}$ & Monitors drivers fatigue level and warns driver in advance of the onset of sleep \\
\hline $\begin{array}{l}\text { Vehicle Diagnostic } \\
\text { Reporting Systems }\end{array}$ & Presents driver with performance and current status of critical vehicle systems \\
\hline $\begin{array}{l}\text { Rear Parking } \\
\text { Sensors/Cameras }\end{array}$ & $\begin{array}{l}\text { Warns driver when reversing of objects in close proximity to the vehicle. } \\
\text { Camera-based systems allow the driver to see what is behind the vehicle }\end{array}$ \\
\hline $\begin{array}{l}\text { Vision Enhancement } \\
\text { Systems }\end{array}$ & Enhances driver vision in low visibility or dark conditions via head up display \\
\hline $\begin{array}{l}\text { Route Navigation } \\
\text { Systems }\end{array}$ & $\begin{array}{l}\text { Provides driver with navigation assistance e.g. selects routes, provides turn-by- } \\
\text { turn instructions etc }\end{array}$ \\
\hline $\begin{array}{l}\text { In-Vehicle Road Sign } \\
\text { Display Systems }\end{array}$ & Displays proximal road signs to driver within the vehicle \\
\hline $\begin{array}{l}\text { Automatic Crash } \\
\text { Notification Systems }\end{array}$ & $\begin{array}{l}\text { Automatically dials the emergency services in the event of a crash, providing } \\
\text { GPS coordinates and crash severity details }\end{array}$ \\
\hline $\begin{array}{l}\text { Lane Change Support } \\
\text { Systems }\end{array}$ & $\begin{array}{l}\text { Provides assistance to drivers when changing lanes by detecting vehicles behind } \\
\text { and to the side of the vehicle (that may be in blind-spot areas) }\end{array}$ \\
\hline $\begin{array}{l}\text { Co-operative vehicle- } \\
\text { highway systems }\end{array}$ & $\begin{array}{l}\text { Allows vehicles to communicate with each other and road infrastructure to warn } \\
\text { of congestion, accidents and other dangerous traffic conditions }\end{array}$ \\
\hline $\begin{array}{l}\text { Electronic Mirror } \\
\text { Systems }\end{array}$ & Present driver with an image of other vehicles located in blind spots \\
\hline $\begin{array}{l}\text { Combined Active and } \\
\text { Passive Systems }\end{array}$ & $\begin{array}{l}\text { Detects impending collision/crash and triggers advanced safety systems e.g. } \\
\text { seatbelt pre-tensioners }\end{array}$ \\
\hline $\begin{array}{l}\text { Location Specific } \\
\text { Alerting and Warning }\end{array}$ & $\begin{array}{l}\text { Warn driver of locations to be avoided or approached with caution e.g. accident } \\
\text { scenes, congested areas, fog etc }\end{array}$ \\
\hline
\end{tabular}


The ADS overlaid with potential ITS solutions is presented in Table 5. Within Table 5 , potential ITS solutions are proposed for the information requirements specified in Table 2, and also the driving tasks requiring support specified above. For example, the information requirement 'road rules and regulations' could be supported through systems such as intelligent speed adaptation systems that present speed limits to the driver and also warn the driver when the speed limit is being exceeded. Further, vehicle and cognitive control tasks could be supported by ITS technologies such as adaptive cruise control, lane departure warning systems and following distance-warning systems.

Table 5. ADS containing potential ITS solutions for information requirements

\begin{tabular}{|c|c|c|c|}
\hline & $\begin{array}{l}\text { Total System (Victorian Roac } \\
\text { Transport System) }\end{array}$ & Sub-System (Driving System) & Component (Road users, vehicles etc) \\
\hline $\begin{array}{l}\text { Functional } \\
\text { Purpose }\end{array}$ & $\begin{array}{c}\text { Information-related to road rules and } \\
\text { regulations } \\
\text { Enforcement devices e.g. Intelligent Speec } \\
\text { Adaptation } \\
\text { In-vehicle road sign display systems }\end{array}$ & & $\begin{array}{l}\text { Electronic driver licensing system } \\
\text { Vehicle condition and roadworthiness indication } \\
\text { system }\end{array}$ \\
\hline Abstract Function & 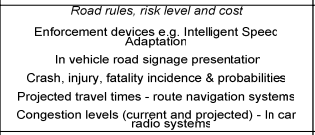 & & $\begin{array}{c}\text { Personal goals, risk level and cost } \\
\text { Economic cost - MPG displays } \\
\text { Journey risk indicator } \\
\text { Route navigation system } \\
\text { Diagnostic Vehicle condition and performance } \\
\text { reporting system }\end{array}$ \\
\hline $\begin{array}{l}\text { Generalised } \\
\text { Functior }\end{array}$ & $\begin{array}{c}\text { Information-related to road rules and } \\
\text { regulations and behavioural requirements } \\
\text { Enforcement devices e.g. Intelligent Speec } \\
\text { Adaptation } \\
\text { Behavioural Recommendation System } \\
\text { Warning System } \\
\text { In-vehicle road sign display systems }\end{array}$ & $\begin{array}{l}\text { Information-related to road rules and } \\
\text { regulations } \\
\text { Enforcement devices e.g. Intelligent Speec } \\
\text { Adaptation } \\
\text { In-vehicle road sign display systems }\end{array}$ & 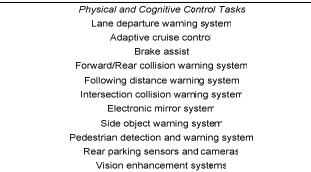 \\
\hline Physical Function & & $\begin{array}{l}\text { Route information and occupant Protectior } \\
\text { Route navigation system } \\
\text { Seat belt reminder/linterlock systems } \\
\text { Crash notification syster } \\
\text { Active and Passive safery systems } \\
\text { Seat-belt pretensioners } \\
\text { Physical dynamics (own nand other vehicles) }\end{array}$ & 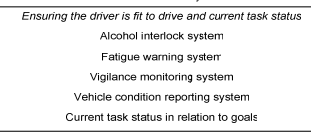 \\
\hline Physical Form & $\begin{array}{c}\text { Road name, type and environmental conditions } \\
\text { Route navigation system } \\
\text { In-car radio (Weather forecast) } \\
\text { Co-operative vehicle highway systems } \\
\text { Location specific alerting/warning systems }\end{array}$ & & 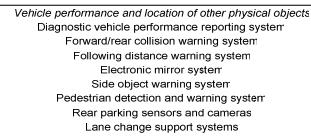 \\
\hline
\end{tabular}

We wish to point out that we do not claim that the solutions presented in Table 5 are novel, and nor do we claim that the ITS technologies discussed have not been previously described within the literature. Rather we present the ADS as a method for deriving driver information requirements and for identifying driving tasks that require additional support. We argue that, in this way, the ADS methodology can be used to identify existing technologies that can potentially provide this information and/or support.

By way of an example, for enforcing compliant behaviour, supporting the comprehension and understanding of road rules and regulations and presenting road signage information within the vehicle, ITS devices such as intelligent speed adaptation (ISA) could potentially be used. ISA systems visually present the current speed limit to the driver and provide an audible warning when the speed limit is being exceeded. More advanced systems also limit vehicle speed by applying the brakes and through the application of upward pressure on the accelerator. Similar systems linked to a global positioning system (GPS) device could also be used to present all road signage-related information (e.g. speed limits, directions, route information etc) within the vehicle and also to issue behavioural recommendations (e.g. slow down) and warnings (e.g. sharp 
bend ahead). There are many potential benefits associated with presenting road signage related information within the vehicle. For example, Regan (2004b) highlights several, including the ability of drivers to display road signage information within the vehicle as and when they want it (e.g. earlier than current road signs, or post road sign in the event of missing the information), for as long as they want to and as often as they like. Further benefits include the ability to display road signage information in ones own language, and also in either auditory or visual formats.

For occupant protection, systems such as seat belt reminders, seat belt interlock, seat belt pre-tensioners, and automatic crash notification systems could be used to both enforce and enhance occupant protection. Such systems could not only ensure that all occupant protection devices are actively used, but also that in the event of a crash, the devices are working optimally and that the relevant emergency services are notified of the crash. ITS technologies could also play a role in ensuring the driver is fit to drive. For example, alcohol interlock devices (which prevent the vehicle being driven if the driver is inebriated and are already in use for recidivist drink drivers), fatigue monitoring devices and electronic licensing systems could be used to prevent drivers from driving who are in an unfit state or who are unqualified to drive. Indeed, according to the O’Donnell (2006) New York State legislators are considering making alcohol ignition interlock devices a standard requirement for all cars and trucks by 2009, and such devices are close to being offered as optional extras on all Volvo and Saab models.

Support for both physical and cognitive vehicle control tasks are also offered by ITS systems. Systems such as lane departure warning systems, following distance warning systems, adaptive cruise control and route navigation systems all aid the driver in driving safely and optimally. It is also apparent that behavioural recommendation devices could be used within vehicles to support safe and efficient driving. Such devices could issue warnings or behavioural advice to the driver, such as a 'slow down' warning prior to a sharp bend in the road, or other advice and warnings related to vehicle separation and position in the road etc.

In terms of information requirements that are not satisfied by contemporary vehicle systems, it appears that ITS technology could potentially be used to provide this information. For example, information related to other road users and vehicles (e.g., location, proximity and dynamics) could be presented to the driver through electronic mirror systems, side object warning systems or on-board displays. Devices warning the driver of proximal road users are already advanced, such as rear parking sensor systems and pedestrian detection and warning systems. Information and support related to road type and layout and navigational tasks is presented by route navigation systems, yet such systems are still not standard on all production vehicles. Similarly, traffic and congestionrelated information is typically presented to drivers via local radio and route navigation systems. Information related to crash and injury probability and risk level is currently not presented in-vehicles and nor is it presented by any of the ITS technologies considered. Economic cost of journey is not presented per se, but is often presented in-directly via vehicle performance displays such as current mile per gallon displays. Information related to vehicle condition and roadworthiness is presented, albeit in a limited way (e.g. next service date, oil warning light). It is feasible that this could be presented in greater detail to the driver via novel ITS systems. This might involve issuing warnings to the 
driver when vehicle components require maintenance (i.e. new brake pads required) or when the vehicles MOT expiration date is approaching. For example, the Nissan Primera currently has a function that presents information regarding the next service and MOT dates to the driver (Jenkins, 2006). Further, information related to the condition of different vehicle components could also be presented to the driver, such as warnings regarding the condition of the vehicles tyres (e.g. tyre tread low warning) or the need for an oil change.

\subsection{Human Factors Implications}

Integrating additional interfaces and systems, such as ITS, into the vehicle raises a number of issues, particularly in relation to the effects these devices have on driver performance and behaviour. When investigating the integration of additional interfaces and systems within vehicles consideration should be given to the effects on driver workload, situation awareness, the driver distraction, driver errors, behavioural adaptations, over-reliance, risk exposure, and acceptance. It is beyond the scope of this article to discuss these human factors issues in detail here. Rather, the reader is referred to Regan (2004b, 2005) for a broader discussion of the key human factors issues related to the use of ITS.

\section{Conclusion}

The aim of this research was to investigate the potential use of WDA to inform the vehicle system design process. Specifically, WDA was used to identify the information that drivers require for safe, compliant and efficient driving, and also a range of driving tasks that might require additional support from in-vehicle technology. In relation to vehicle design, it was concluded that the majority of the information requirements identified by a WDA of the Victorian road transport system are currently adequately presented by in-vehicle interfaces and displays and road transport infrastructure (e.g. road signage and markings). However, it was concluded that some of the information requirements identified by the WDA are currently not presented to the drivers via invehicle displays and interfaces. Further, although some of this information is presented via other sources external to the vehicle (e.g. road signage, traffic control devices), it is concluded that it could potentially be presented by in-car systems, which has a range of associated benefits to the driver. Information required by drivers that is currently not presented at all was also identified. It was therefore concluded that contemporary production vehicles do not entirely provide the required information directly to drivers, and therefore that current vehicle interfaces do not fully support safe, compliant and efficient driving.

The potential use of ITS technologies identified within the literature to circumvent these 'information gaps' was investigated, and it was concluded that there are a range of ITS technologies (currently either available or in prototype form) that could potentially present the required information. These included ISA, electronic mirror systems, side object warning systems, and route navigation systems. Further, a range of novel ITS technologies that could support the driver information requirements were also discussed, including vehicle condition warning systems (e.g. Next service, MOT and tyre tread warning devices) and behavioural recommendation and warning devices (e.g. 'slow down' or 'keep left' warnings). 
The driving tasks identified that drivers could potentially require additional support on included road sign delineation, understanding/comprehension of road rules (e.g. speed limits), location/future actions of other road users, physical vehicle control tasks, cognitive vehicle control tasks, compliant driving and ensuring the driver is fit to drive. ITS technology that could support these tasks were also identified from the literature, including occupant protection devices (seat-belt interlock and reminder, alcohol interlock and fatigue monitoring systems), lane departure warning systems, adaptive cruise control, following distance warning, forward collision warning and intersection collision warning systems, and route navigation systems.

It is recommended that further investigation into the integration of ITS technologies within production vehicles be conducted. This article attempts to facilitate this process by tentatively pinpointing the informational and support requirements that ITS technologies could potentially be used to satisfy, and also by identifying the types of ITS technologies that could be used. Further research is now required. In particular, the effects on driver behaviour and performance of introducing ITS technologies into the vehicle should be explored further. Only when these effects are fully understood can consideration be given to the integration additional ITS technologies into production vehicle cockpits.

It is our opinion that there is significant scope for further CWA applications in the road transport system design process. It is notable that previous applications of CWA in a vehicle design context are limited. Stoner, Wiese and Lee (2003) developed an abstraction hierarchy for the driving domain to verify whether driver support systems such as collision avoidance systems were displaying the appropriate information, and in an appropriate manner to drivers. In conclusion Stoner et al (2003) suggested that the AH of the driving domain identified important information that is not normally considered in the design of driver support systems, including traffic flow stability and peripheral and probabilistic obstacles.

It is the opinion of the authors that CWA-related methods could potentially be used to inform the design of vehicles, road transport-related systems (e.g. road infrastructure, road signage, traffic control devices, ITS technologies etc) and also driver training programs. Further, it is apparent that CWA methods could also be used in the evaluation of vehicle and road transport systems. It is recommended, therefore, that additional road transport system design-related research utilising the other phases and methods of the CWA framework be conducted, and that the integration of EID principles in the vehicle design process through the use of the CWA framework be considered.

In closing, we argue that WDA has been useful for defining driver information requirements and additional roles for ITS technologies within production vehicles. The utility of WDA as a design tool in this case lies in its ability to generate a comprehensive series of information requirements that drivers need during the driving task. Further, the output of WDA allows tasks that are not currently supported by interfaces within a particular system to be identified. The generic nature of the methodology ensures that it can be applied in a similar way in any domain, and this has been demonstrated by previous research that has used WDA in this manner (e.g. Salmon et al, 2004; Alhstrom, 2005, Stoner et al, 2003). 


\section{References}

Ahlstrom, U. (2005) Work domain analysis for air traffic controller weather displays. Journal of Safety Research, 36, 159-169.

Bisantz, A. M., Roth, E., Brickman, B., Gosbee, L. L., Hettinger, L., \& McKinney, J. (2003). Integrating cognitive analyses in a large-scale system design process. International Journal of Human-Computer Studies, 58, 177-206.

Burns, C. B., \& Hajdukiewicz, J. R. (2004). Ecological interface design. CRC Press, Boca Raton, USA.

Hajdukiewicz J. R. (1998). Development of a structured approach for patient monitoring in the operating room. Masters Thesis. University of Toronto

Higgins, P. G. (1998). Extending cognitive work analysis to manufacturing scheduling. In Proceedings of OzCHI'98, November 30-December 4, 236-243.

Jenkins, D. P. (2006). Personal correspondence.

Miller, A. (2004). A work domain analysis framework for modelling intensive care unit patients. Cognition, Technology and Work.

Naikar, N., Pearce, B., Drumm, D. \& Sanderson, P. M. (2003). Technique for designing teams for first-of-a-kind complex systems with cognitive work analysis: Case study. Human Factors, 45(2), 202-217.

Naikar, N., Moylan, A., \& Pearce, B. (In Press). Analysing activity in complex systems with cognitive work analysis: concepts, guidelines, and case study for control task analysis. Theoretical Issues in Ergonomics Science.

Naikar, N., Hopcroft, R. \& Moylan, A. (2005). Work domain analysis: Theoretical concepts and methodology. DSTO Technical Report (DSTO-TR-1665). Edinburgh, Australia: System Sciences Laboratory.

Naikar, N. \& Saunders, A. (2003). Crossing the boundaries of safe operation: A technical training approach to error management. Cognition Technology and Work, 5, 171-180.

Naikar, N. \& Sanderson, P.M. (2001). Evaluating design proposals for complex systems with work domain analysis. Human Factors, 43, 529-542.

O’Donnell, J. (2006). Will all autos some day have breathalysers? USA Today, April 25th, 2006.

Olsson, G. \& Lee, P. L. (1994). Effective interfaces for process operators. The Journal of Process Control, 4, 99-107.

Ormerod, T. C., \& Shepherd, A. (2005). Using task analysis for information requirements specification: The Sub Goal Template method. In D. Diaper \& N. Stanton (Eds.) The 
Handbook of Task Analysis for Human-Computer Interaction. London: Lawrence Erlbaum Associates, pp 347-365.

Regan, M.A. (2004a). A Sign of the Future - 1: Intelligent Transport Systems. In Castro, C. and Horberry, T. (Eds). The Human Factors of Transport Signs. USA: CRC Press. pp 213-224.

Regan, M.A. (2004b). New technologies in cars: Human factors and safety issues. Ergonomics Australia, 18 (3), pp 6-15.

Regan, M.A., Young, K., Triggs, T., Tomasevic, N., Mitsopoulos, E., Tierney, P., Healy, D., Connelly, K and Tingvall, C. (2005). Effects on driving performance of In-Vehicle Intelligent Transport Systems: Final Results of the Australian TAC SafeCar Project. In the Proceedings of the 2005 Australasian Road Safety Research, Policing and Education Conference, Wellington, New Zealand, 14-16 November 2005. (ISBN 0-473-10637-X)

Regan, M. A, (2005). Intelligent transport systems and safer vehicles. Regan, M.A., Langford, J., Johnston, I. \& Fildes, B. (2005). Intelligent Transport Systems and Safer Vehicles. In Austroads Road Safety Handbook. Sydney, Australia: Austroads.

Salmon, P.M., Stanton, N., Walker, G., \& Green, D. (2004). Future battlefield visualisation: Investigating data representation in a novel C4i system. In V. Puri, D. Filippidis, P. Retter \& J. Kelly (Eds.) Weapons, Webs and Warfighters. Proceedings of the Land Warfare Conference, DSTO, Melbourne, 2004.

Salmon, P. M., Stephan, K., Lenne, M., \& Regan, M. (2005). Cognitive work analysis and road safety: Potential applications in road transport. In proceedings of the Road Safety Research Policing Education Conference 2005, Wellington, New Zealand, November 14 - 16.

Stoner, H. A., Wiese, E. E., \& Lee, J. D. (2003). Applying ecological interface design to the driving domain: the results of an abstraction hierarchy analysis. In Proceedings of the Human Factors and Ergonomics Society 47th Annual Meeting, Santa Monica, CA, 444-448.

Vicente, K.J. (1999). Cognitive work analysis: Towards safe, productive, and healthy computerbased work. Mahwah, NJ: Lawrence Erlbaum Associates, Inc. 